\title{
T-47D Meme Kanseri Hücreleri Üzerinde Kurkuminin Doz Bağımlı Etkisinin İncelenmesi
}

\author{
Nuriye Ezgi BEKTUR AYKANAT ${ }^{1}$, Sedat KAÇAR ${ }^{2}$
}

1 Atılım Üniversitesi Tıp Fakültesi, Histoloji ve Embriyoloji Anabilim Dalı, Ankara.

2 Eskişehir Osmangazi Üniversitesi Tıp Fakültesi, Histoloji ve Embriyoloji Anabilim Dalı, Eskişehir.

\section{ÖZET}

Zingiberaceae familyasına ait zerdeçaldan elde edilen bir polifenol olan kurkumin, anti-inflamatuar, anti-tümör, anti-oksidatif ve antimikrobiyal etkiler dahil olmak üzere birçok etkiye sahiptir. Kurkuminin farklı kanser hücreleri üzerindeki etkileri hakkında birçok çalışma bulunmaktadır. Bu çalışma, kurkuminin T-47D meme kanseri hücre canlılığı üzerindeki anti-kanser etkisini araștırmayı amaçlamaktadır. T-47D meme kanseri hücrelerine farklı dozlarda uygulanan kurkuminin etkisi MTT yöntemi ve inverted mikroskop ile araştırılmıştır. Kurkuminin T-47D hücrelerinde IC50 dozu 24 saat sonunda $65,8 \mu \mathrm{M}$, 48 saat sonunda $46,4 \mu \mathrm{M}$ ve 72 saat sonunda ise $26,6 \mu \mathrm{M}$ olarak belirlenmiștir. Morfolojik değerlendirmede ise kurkumin uygulanmış hücreler yuvarlak ve flask yüzeyinden ayrılmış kitleler halinde gözlenmektedir. Sonuçlarımız, kurkuminin T-47D hücre proliferasyonunu önemli ölçüde azalttığını göstermektedir. Kurkumin, tek başına veya diğer moleküllerle kombinasyon halinde meme kanseri tedavisi için bir aday olabilir. Gelecekte, kurkuminin meme kanseri hücreleri üzerindeki etki mekanizmasını aydınlatmak için daha kapsamlı ve çok merkezli destekli ileri klinik çalışmalara ihtiyaç vardır.

Anahtar Kelimeler: Kurkumin. Meme Kanseri. Sitotoksisite.

Investigation of Dose-Dependent Effect of Curcumin on T-47D Breast Cancer Cells

\begin{abstract}
Curcumin, a polyphenol derived from turmeric belonging to the Zingiberaceae family, has multiple effects, including anti-inflammatory, antitumor, anti-oxidative and antimicrobial effects. There are many studies on the effects of curcumin on different cancer cells. This study aims at investigating the anti-cancer effect of curcumin on T-47D breast cancer cell. T-47D breast cancer cells will be examined by MTT assay and inverted microscopy. IC ${ }_{50}$ doses are $65.8 \mu \mathrm{M}$ for $24 \mathrm{~h}$-long MTT, $46.4 \mu \mathrm{M}$ for $48 \mathrm{~h}$-long MTT and $26.6 \mu \mathrm{M}$ for $72 \mathrm{~h}$-long MTT assay. In the inverted microscope, curcumin-treated cells appear to be rounded and detached from the bottom flask with a massive morphology. Our results showed that curcumin significantly reduced T-47D cell proliferation. Curcumin may be a candidate for breast cancer therapy, either alone or in combination with other molecules. In the future, more comprehensive and multicenter-supported advanced clinical studies are needed to elucidate the mechanism of action of curcumin on breast cancer cells.
\end{abstract}

Key Words: Curcumin. Breast Cancer. Cytotoxicity.

Dünya genelinde kadınlarda en sık görülen kanser türü olan meme kanseri, gelişmiş ülkelerde daha yüksek prevalansı ile tüm kadın malignitelerinin yaklaşık \%25'ini oluşturmaktadır. Meme kanseri gelişimi

Geliş Tarihi: 06.Temmuz.2021

Kabul Tarihi: 17.Ağustos.2021

Dr. Nuriye Ezgi BEKTUR AYKANAT

Atıım Üniversitesi Tıp Fakültesi,

Histoloji ve Embriyoloji Anabilim Dalı,

Kızılcaşar Mahallesi Gölbaşı,

Ankara

Tel.: 05344111979

E-posta Adresi: ezgi.bektur@gmail.com

Yazarların ORCID ID Bilgisi:

Nuriye Ezgi BEKTUR AYKANAT: 0000-0003-1453-7311

Sedat KAÇAR: 0000-0002-0671-8529 östrojen düzeyi, diyet, kalıtsal yatkınlık ve obezite gibi çeşitli faktörlerle ilişkilidir. Bu faktörler, gen mutasyonlarına, hücre döngüsü anormalliklerine ve PI3K, mTOR, MAPK, östrojen reseptörü (ER) ve CDK'ler gibi sinyal yollarındaki değişiklikler dahil olmak üzere epigenetik modifikasyon kontrolünün kaybına neden olmaktadır. Meme kanseri tanı ve tedavisinde son yıllarda önemli ölçüde gelişme katedilmesine rağmen, ilerlemiş meme kanserli hastaların prognozu hala kötüdür ${ }^{1-3}$.

Yaygın olarak kullanılan baharat zerdeçalın (Curcuma longa Linn) sarı renginden sorumlu, doğal olarak oluşan bir fitokimyasal olan kurkumin (1,7-bis(4hidroksi-3-metoksifenil), Curcuma longa bitkisinden elde edilir. Anti-inflamatuar, anti-oksidatif ve antitümör etkilerinin yanı sıra anti-proliferatif ve apoptotik etkileri nedeniyle, kolon ve mide gibi bazı kanser 
modellerinde klinik onkolojide kemopreventif bir ajan olarak kapsamlı bir şekilde çalışılmış ve terapötik bir ajan olarak kullanılmaktadır. Kurkumin, inflamatuar sitokinler ve enzimler, transkripsiyon faktörleri, hücrenin hayatta kalması ve proliferasyonu ile ilişkili genlerin ekspresyonunu ve aktivitelerini etkiler ${ }^{1,2,4,5}$.

Kurkuminin anti-kanserojen özelliği, hayvanlarda hem çeşitli kanserojenler hem de forbol esterler tarafindan indüklenen tümör oluşumunun inhibisyonu ile gösterilmiştir. Ksenotransplant veya ortotransplant hayvan modellerinde, insan tümörlerinin büyümesi, kurkuminin tek başına veya kemoterapötik ajanlar/radyasyon ile kombinasyon halinde kullanılmasıyla inhibe edilmiştir. Hücre çalışmalarında, tümör hücrelerinin proliferasyonunu inhibe ettiği gözlenmiştir ${ }^{1}$.

Çok hücreli bir organizmada çeşitli fizyolojik ve/veya patolojik koşulların neden olduğu programlanmış hücre ölümüne apoptoz denir. Sisplatin, kamptotesin gibi kemoterapötik veya anti-tümör ajanların hedef tümör hücrelerinde apoptoza neden olduğuna dair birikmiş kanıtlar vardır. Bu bağlamda kemopreventif ajanların apoptozu indüklemesi dikkat çekicidir ${ }^{6}$.

Sunulan çalışmamızda farklı dozlardaki kurkuminin T-47D meme kanseri hücreleri üzerindeki etkilerini 24, 48 ve 72 saat sonunda göstermeyi amaçladık. Yapt1ğımız literatür taramalarında kurkuminin genellikle 24 ve 48 saatteki etkinliği çalışılırken T-47D meme kanseri hücreleri üzerinde 72 saatteki etkinliğinin ve dozlarının çalışılmadığını gözlemledik. Çalışmamız diğer araştırmacılar tarafindan yapılacak çalışmalar için referans olacak bir çalışmadır.

\section{Gereç ve Yöntem}

\section{Hücre Kültürü}

ATCC firmasından satın alınan T-47D hücre hatt1 $\% 10(\mathrm{~h} / \mathrm{h})$ Fetal Bovine Serum ve $\% 1(\mathrm{~h} / \mathrm{v})$ penisilin-streptomisin içeren RPMI-1640 hücre medyumunda $37{ }^{\circ} \mathrm{C}$ 'de ve \%5 $\mathrm{CO}_{2}$ içeren inkübatör içerisinde çoğaltıldı. Medyum, hücre ortamındaki fenol kırmız1sinın renk değişimine bağlı olarak haftada 2-3 kez yenilendi. Pasajlama işleminde, hücreleri kaldırmak için \%0,05 tripsin/0,53 mM EDTA solüsyonu kullanildi.

\section{MTT testi}

MTT yöntemi, hücre canlılığının belirlenmesi için sıklıkla kullanılan ve spektrofotometre ile ölçülen yaygın bir kolorimetrik sitotoksisite testidir. MTT, hücreler tarafindan aktif olarak emilen bir maddedir. Mitokondriyal reaksiyonla renkli, suda çözünmeyen bir formazana indirgenir. Hücre canlılığı, her hücrenin MTT indirgeme özelliği ile ölçülür ve MTT analizi sonucunda elde edilen boya yoğunluğu canlı hücre sayısı ile orantılidir ${ }^{7}$.
Kurkuminin T-47D meme kanseri hücreleri üzerindeki sitotoksisitesi veya hücreler üzerindeki canlılığı arttırıcı etkisi MTT yöntemi ile belirlendi. T-47D hücreleri kuyu başına 5000 hücre olacak şekilde ekildi ve 24 saat sonra hücrelere kurkuminin farklı dozları verildi. Hücreler, 96'lı plakanın her bir oyuğuna 1/10 MTT (Boster Biyolojik Teknoloji, Pleasanton, CA, USA, Katalog \# AR1156) eklenerek $37^{\circ} \mathrm{C}^{\prime}$ de 4 saat inkübe edildi. İnkübasyon süresinin sonunda her kuyudaki besiyeri pipetlendi ve $100 \mu \mathrm{L}$ DMSO eklendi ve kuyucuklar çalkalayıcı üzerinde 5-8 dakika çalkalandı. Kuyucuklarda oluşan formazan tuzu kristalleri mikroskop altında kontrol edildi ve ardından bu kristalleri çözmek için $100 \mu \mathrm{L}$ DMSO uygulandı. Sonunda, 96 kuyucuklu plaka bir mikroplaka okuyucusunda (800TS, BioTek Instruments, Winooski, VT, US) 570 nm'de analiz edildi. Kurkumin ile muamele edilmiş kuyulardan okunan optik yoğunluk, kontrole karş1 canlı hücrelerin yüzdesine dönüştürüldü. Elde edilen veriler, kontrolün ortalama \% fraksiyon \pm standart hata sapması olarak ifade edildi.

\section{Inverted mikroskop}

Hücreler, 6 kuyucuklu plakalarda 5 x $10^{3}$ hücre/kuyu yoğunluğunda çoğaltıldı ve değişen kurkumin dozlarına $(0,30,50$ ve $100 \mu \mathrm{M})$ maruz birakıldı. Daha sonra plakalar inverted mikroskopta (ZEISS Axiovert 135, Oberkochen, Almanya) muamele edilmemiş ve kurkumin ile muamele edilmiş hücrelerde morfolojik değişiklikler ve hücre yoğunluğu açısından 100x büyültme altında incelendi.

\section{İstatistiksel analiz}

MTT verilerinin istatistiksel analizi SPSS yazılımı (Statistics for Windows, Version 21.0. IBM Corp. Armonk, NY, ABD) kullanılarak yapıldı. Sirasıyla Shapiro-Wilk testi ve Levene testi ile analiz edilen tüm veriler normal dağılım gösterdi ve homojen bir varyansa sahipti. Bu nedenle, post hoc Tukey testi ile tek yönlü bir varyans analizi yapıldı. İstatistiksel anlamlılık $\mathrm{p}<0,05, \mathrm{p}<0,01$ ve $\mathrm{p}<0,001$ olarak ifade edildi.

\section{Bulgular}

\section{Kurkuminin Sitotoksik Etkisi}

T-47D hücrelerinde zamana (24, 48 ve 72 saat) ve kurkuminin doza $(0,5,10,20,30,40,50$ ve $100 \mu \mathrm{M})$ bağlı sitotoksik analizi yapıldı. Tablo I, hücre canlıl1ğının yüzdelerini ve istatistiksel olarak anlamlılık düzeyini göstermektedir.

Kurkuminin T-47D hücrelerinde IC50 konsantrasyonları, doz-canlılık grafiği aracılığıyla hesaplandı. Kurkuminin T-47D hücrelerinde IC50 dozu 24 saat sonunda $65,8 \mu \mathrm{M}$ bulunmuştur. $5 \mu \mathrm{M}$ kurkumin hücre proliferasyonuna neden olsa da kontrol grubu ile kar- 


\section{Kurkumin Meme Kanseri Hücre Proliferasyonunu Engeller}

ş1laştırıldığında istatistiksel olarak anlamlı değildi ( $>>0.05)$. Kontrol ve $10 \mu \mathrm{M}$ kurkumin uygulamas1 sonucunda hücre canlılığı birbirine yakındı. 20 ve 30 $\mu \mathrm{M}$ kurkumin uygulaması hücrelerde bir miktar proliferasyona neden olsa da istatistiksel olarak anlaml değildi ( $>00.05$ ). Ancak $40 \mu \mathrm{M}$ kurkumin hücre canl1lığını \%69,8'e $(\mathrm{p}<0.01)$ ve $50 \mu \mathrm{M}$ kurkumin ise hücre canlılığını \%72,8'e $(\mathrm{p}<0.01)$ düşürdü. Son olarak, hücre canlılığ1 $100 \mu$ M'de \%0,7'ye düştü $(p<0.001)$ (Şekil 1, Tablo I).
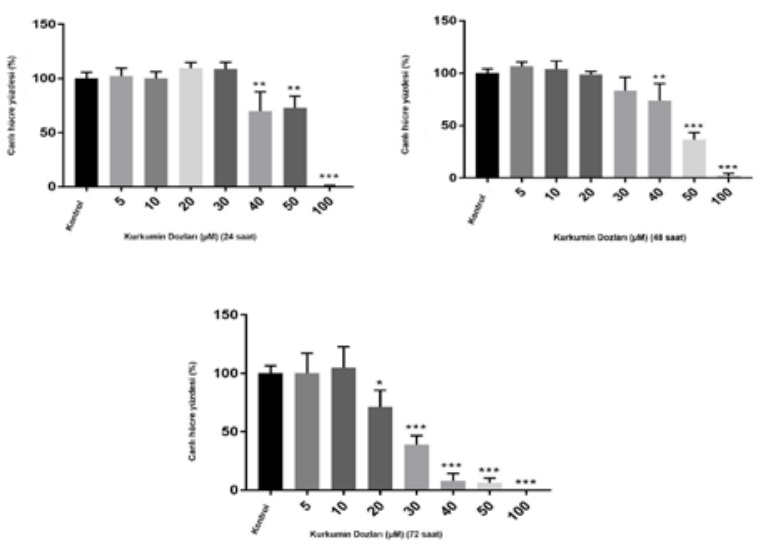

Şekil 1.

24, 48 ve 72 saat boyunca farklı kurkumin dozlarl uygulanmış T-47D hücrelerinin canlılı̆̆ ve istatistiksel anlamlılık dereceleri. Sonuçlar ortalama \pm SS olarak görüntülenir. *, ** ve ***, kontrol grubu hücreleri ile karşılaştırıldığında sırasıyla $p<0.05, p<0.01$ ve $p<0.001$ 'lik istatistiksel farklıllkları gösterir.

Tablo I. 24, 48 ve 72 saat sonunda $0-100 \mu \mathrm{M}$ dozlar arasında kurkumin uygulamasından sonra T-47D meme kanseri hücrelerinin hücre canlılığının yüzdesi.

\begin{tabular}{|lccc|}
\hline \multirow{2}{*}{$\begin{array}{l}\text { Kurkumin } \\
\text { Dozları }(\mu \mathrm{M})\end{array}$} & \multicolumn{3}{c|}{$\begin{array}{l}\text { Hücre Canlıı̆ı }(\%) \\
\text { (ortalama } \pm S S)\end{array}$} \\
\cline { 2 - 4 } & $\mathbf{2 4 h}$ & $\mathbf{4 8} \mathrm{h}$ & $\mathbf{7 2 ~ h}$ \\
\hline Kontrol $(\mathbf{0} \mu \mathrm{M})$ & $100.0 \pm 5.7$ & $100.0 \pm 4.1$ & $100.0 \pm 6.7$ \\
5.0 & $102.3 \pm 7.3$ & $106.5 \pm 4.1$ & $100.0 \pm 17.1$ \\
10.0 & $100.0 \pm 6.2$ & $104.0 \pm 7.6$ & $104.9 \pm 18.0$ \\
20.0 & $109.4 \pm 5.2$ & $98.9 \pm 3.0$ & $71.5 \pm 14.0^{\mathrm{a}}$ \\
30.0 & $108.8 \pm 5.9$ & $83.5 \pm 12.7$ & $39.0 \pm 7.7^{\mathrm{c}}$ \\
40.0 & $69.8 \pm 17.9^{\mathrm{b}}$ & $73.9 \pm 16.1^{\mathrm{b}}$ & $7.9 \pm 6.3^{\mathrm{c}}$ \\
50.0 & $72.8 \pm 11.0^{\mathrm{b}}$ & $36.6 \pm 6.8^{\mathrm{c}}$ & $6.3 \pm 4.0^{\mathrm{c}}$ \\
100.0 & $0.7 \pm 0.4^{\mathrm{c}}$ & $1.8 \pm 2.5^{\mathrm{c}}$ & $0.0 \pm 2.0^{\mathrm{c}}$ \\
\hline
\end{tabular}

a: anlaml fark $\mathrm{p}<0.05$, b: anlaml fark $\mathrm{p}<0.01$ and $\mathrm{c}$ : anlaml fark $\mathrm{p}<0.001$ kontrol grubu ile karşılaştırıldığında.

Kurkuminin T-47D hücrelerinde IC50 dozu 48 saat sonunda $46,4 \mu \mathrm{M}$ bulunmuştur. $5 \mu \mathrm{M}$ ve $10 \mu \mathrm{M}$ kurkumin bir miktar proliferasyona neden olsa da istatistiksel olarak anlamlı değildi ( $\mathrm{p}>0.05) .20 \mu \mathrm{M}$ kurkumin'de hücre canlılığ $\% 98,9$ 'a ve $30 \mu \mathrm{M}$ kurkuminde hücre canlılığ1 \%83,5'e düştü ancak hücre azalması istatistiksel olarak anlamlı değildi $(\mathrm{p}>0.05)$. Bununla birlikte, $40 \mu \mathrm{M}$ kurkuminde hücre canlılığg $\% 73,9$ 'a $(\mathrm{p}<0.01)$ ve $50 \mu \mathrm{M}$ kurkuminde hücre canlı11$\breve{g}_{1} \% 36,6$ 'ya $(\mathrm{p}<0.001)$ düştü. Son olarak, hücre canl1lığ1 100 uM'de \%1,8'e düşmüştür (kontrol ile karşılaştırıldığında $\mathrm{p}<0.001$ ) (Şekil 1, Tablo I).

Kurkuminin T-47D hücrelerinde IC50 dozu 72 saat sonunda 26,6 $\mu \mathrm{M}$ bulunmuştur. Kontrol ve $5 \mu \mathrm{M}$ kurkuminin canlılık düzeyleri birbirine yakın bulundu.10 $\mu \mathrm{M}$ kurkumin bir miktar proliferasyona neden olsa da istatistiksel olarak anlamlı değildi ( $\mathrm{p}>0.05)$. Bununla birlikte, $20 \mu \mathrm{M}$ kurkumin hücre canlılığ1n1 \%71,5'e ( $\mathrm{p}<0.05), 30 \mu \mathrm{M}$ kurkumin ise hücre canl1lığını \%39,0'a (kontrol karşısında $\mathrm{p}<0.001$ ), $40 \mu \mathrm{M}$ kurkumin ise \%7,9'a ve $50 \mu \mathrm{M}$ kurkumin'de \%6,3'e düşmüştür (kontrol karşısında $\mathrm{p}<0.001$ ). En yüksek doz olan $100 \mu \mathrm{M}$ uygulamasında, canlılık \%0 idi (kontrol ile karşılaştırıldığında $\mathrm{p}<0.001$ ) (Şekil 1, Tablo I).

\section{Mikroskobi Sonuçları}

Şekil 2'te inverted mikroskoptan alınan görüntüler gösterilmektedir. Kontrol grubunda (A) kurkumin uygulanmamış meme kanseri hücreleri gözlenmektedir.. $20 \mu \mathrm{M}$ (B), $30 \mu \mathrm{M}$ (C) ve $40 \mu \mathrm{M}$ (D) Kurkumin uygulanmış hücreler yuvarlaklaşmış ve flask yüzeyinden ayrılmış hücre toplulukları olarak görünmektedir. T-47D hücrelerinin ölüm oranı, şekli yuvarlaklaşan T47D hücrelerinin artışıyla doğru orantılıdır. Görüntülerde de görüldüğü gibi kurkumin, canlı hücre yoğunluğunu azaltmaktadır.
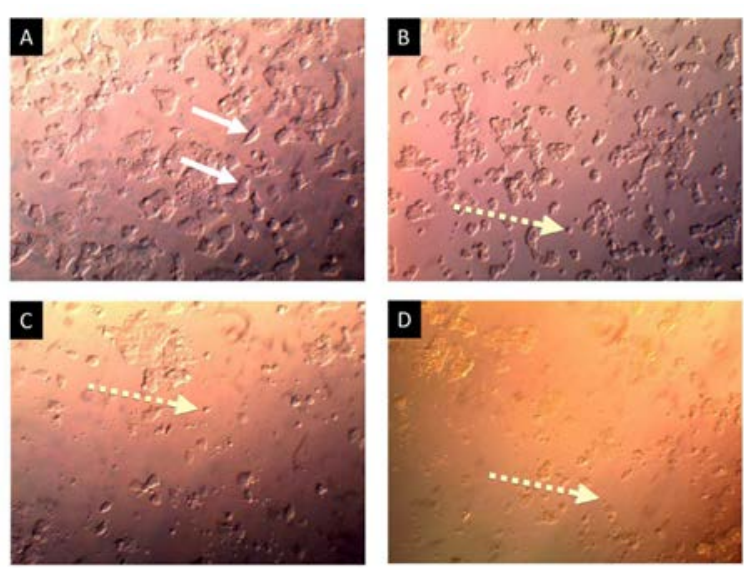

Şekil 2.

T-47D hücre morfolojisi (24 saat): (A) Kurkumin uygulanmamaış kontrol grubu ile, sirasıyla $30 \mu M(B)$, $50 \mu M(C)$ ve $100 \mu M(D)$ konsantrasyonlarinda kurkumin uygulanmış gruplar. Hücre morfolojisi ve miktarl inverted mikroskop kullanılarak gözlemlendi (100x). Kalın oklar normal canlı hücreleri gösterirken, kesikli oklar morfolojisi değişmiş hücreleri (yuvarlak ve/veya yüzeyden ayrılmış hücreler) gösterir. 


\section{Tartışma ve Sonuç}

Vogel ve Pelletier tarafindan 1815'te Curcuma longa'nın (zerdeçal olarak bilinir) rizomlarından ekstre edilen polifenol bileşeni olan kurkuminin, inflamasyon, artrit, metabolik sendrom, karaciğer hastalıkları, obezite ve nörodejeneratif hastalıkların yanı sıra çeşitli kanserleri önleme konusunda da etkin rol oynadığ gösterilmiştir ${ }^{8,9}$.

Sanayileşmiş ülkelerde kanser, başlıca ölüm sebeplerinden biridir. Kanser hücrelerinde apoptozis, proliferasyon ve anjiyogenez sinyal yolları düzensizdir ${ }^{10}$. Son yıllarda kanserin erken teşhis edilip tedavi seçeneklerinin artmasından dolayı ölüm oranları azalmıştır. Ancak ilaca dirençli kanserlerde yenilikçi ve daha etkin ilaçların araştırılması zorunludur ${ }^{9,11}$.

Günümüzde meme kanseri, tüm dünyada kadınlar arasında en yaygın malign tümör olup kanser kaynakl ölüm nedenleri arasında ilk sıralarda yer almaktadır. Meme kanseri vakalarında tedavi ajanı olarak sıklıkla anti-östrojenler kullanılmaktadır. Bununla birlikte, farklı ilaç kombinasyonları meme kanseri tedavisinde çok daha pozitif sonuçlar vermektedir ${ }^{9,12}$. Sunulan çalışmada T-47D meme kanseri hücreleri üzerine kurkuminin doz bağımlı etkisi araştırılmıştır.

Kurkuminin, sağlıklı hücreler üzerinde sitotoksik etkiye neden olmadan malign hücrelerde seçici olarak apoptozu indüklediği düşünülmektedir. Sağlıklı meme hücrelerine, günlük 8000 mg kadar yüksek kurkumin dozu uygulandığında bile çok düşük toksisite ile hemen hemen hiçbir değişiklik oluşturmadığ 1 belirtilmiştir. Klinik onkolojide kurkuminin önemi artmaktadır. Preklinik çalışmalarda kurkuminin meme kanserinin başlaması ve ilerlemesini önlemede etkili olduğunu gösterilmiştir. Yapılan çalışmalar kurkuminin meme kanseri hücrelerinde anjiyogenezi inhibe ederek besin eksikliği ve hipoksiye neden olması sonucunda hücre ölümüne yol açtığını belirtmişlerdir ${ }^{13,14}$.

Çalışmamızda kurkuminin T-47D hücrelerinde doz ve zaman bağımlı olarak sitotoksik etkisini MTT metodu ile belirledik. Kurkuminin T-47D hücrelerinde $\mathrm{IC}_{50}$ dozu 24'üncü saatte $65.8 \mu \mathrm{M}$, 48'ince saatte $46.4 \mu \mathrm{M}$ ve 72 'ince saatte $26.6 \mu \mathrm{M}$ olarak belirlenmiştir. 72 saatin sonunda $20 \mu \mathrm{M}, 30 \mu \mathrm{M}, 40 \mu \mathrm{M}, 50 \mu \mathrm{M}$ ve 100 $\mu \mathrm{M}$ kurkuminin artan dozlarına paralel olarak T-47D meme kanseri hücrelerinin ölümünü arttırdığını gözlemledik. Çalışmamız kurkuminin 24, 48 ve özellikle 72 saatte meme kanseri hücreleri üzerine etkisinin farklı dozlarla gösterilmesiyle doz çalışmalarında referans makale olarak kullanılabilecektir.

Yapılan in vitro çalışmalarda, kurkuminin MCF-7, MDA-MB-468 (MDA468), HCC1937 ve HCC1806 gibi çeşitli hormon-negatif hücre dizilerinde apoptozisi indükleyerek meme kanserinin yayılmasını durdurduğu gösterilmiştir ${ }^{15,16}$. Meme kanseri hücrelerinin proliferasyonu zaman ve doza bağlı bir şekilde kur- kumin tarafından inhibe edilmektedir. Mehta ve arkadaşları BT20, SK-BR-3, MCF-7, T-47D ve ZR75-1 meme kanseri hücre hatlarına kurkumin uygulamasından sonra MTT testi sonucunda meme kanseri hücrelerinin büyümesinin tamamen inhibe edildiğini göstermişlerdir $^{17}$. Chiu ve arkadaşları kurkuminin MDAMB-231 meme kanseri hücrelerinde G2/M döngüsünü bloke ederek doza bağlı olarak hücre proliferasyonunu inhibe ettiğini göstermişlerdir. Ayrıca kurkuminin apoptozu indüklediğini ve NF- $\kappa \beta 65$ 'in protein ekspresyonunu azalttığını ve MDA-MB-231 hücrelerinin göç aktivitesini inhibe ettiğini belirtmişlerdir ${ }^{18,19}$.

Kanser hücrelerinin kurkumin tarafindan seçici olarak öldürüldüğünün kesin mekanizmaları tam olarak açıklanamamıştır. Ayrıca kurkuminin, birden fazla moleküler mekanizmanın kontrolünde kanser kök/ progenitör hücrelerin ve onların soyunun proliferasyonunu baskılayarak anti-kanser özelliğini gösterdiği düşünülmektedir ${ }^{20,21}$.

Sonuç olarak, biyoaktif bileşikler, yeni ajanlar ve biyomarkır moleküller kanser tedavisinde in vivo ve in vitro çalışmalarda araştırılmaktadır. Bu tümörlerin onkogenezisinin ve altında yatan temel mekanizmaların aydınlatılması yeni kanser terapilerin geliştirilmesinin önünü açacaktır. Bu nedenle meme kanser terapisinde yeni biyolojik ve kimyasal reaktiflere ihtiyaç artmaktadir.

Bizim sonuçlarımız kurkuminin T-47D hücre proliferasyonunu anlamlı olarak azalttığını göstermiştir. Kurkumin, meme kanseri terapisi için tek başına ya da diğer moleküllerle kombine olarak kullanılabilecek bir aday olabilir. Gelecekte kurkuminin meme kanseri hücreleri üzerindeki etki mekanizmasını aydınlatacak daha kapsamlı ve çok merkezli desteklenecek ileri düzeyde klinik çalışmalara ihtiyaç bulunmaktadır.

\section{Etik Kurul Onay Bilgisi:}

Hücre kültürü çalışması olmasından dolayı Etik Kurul onayına gerek yoktur.

Araştırmacı Katkı Beyanı: Fikir ve tasarım: N.E.B.A; Veri toplama ve işleme: S.K,; Analiz ve verilerin yorumlanması: N.E.B.A; Makalenin önemli bölümlerinin yazılması: N.E.B.A

Destek ve Teșekkür Beyanı: Bu makalede yer alan çalışmalar herhangi bir kurum tarafindan desteklenmemiştir.

Çıkar Çatışması Beyanı: Makale yazarının çıkar çatışması beyanı yoktur.

\section{Kaynaklar}

1. Liu D, Chen Z. The effect of curcumin on breast cancer cells. J Breast Cancer. 2013;16(2):133-7.

2. $\mathrm{Hu} \mathrm{S}, \mathrm{Xu} \mathrm{Y}$, Meng L, Huang L, Sun H. Curcumin inhibits proliferation and promotes apoptosis of breast cancer cells. Exp Ther Med. 2018;16(2):1266-72.

3. Shen H, Shen J, Pan H, Xu L, Sheng H, Liu B, et al. Curcumin analog B14 has high bioavailability and enhances the effect of 


\section{Kurkumin Meme Kanseri Hücre Proliferasyonunu Engeller}

anti-breast cancer cells in vitro and in vivo. Cancer Sci. 2021;112(2):815-27.

4. Choudhuri T, Pal S, Agwarwal ML, Das T, Sa G. Curcumin induces apoptosis in human breast cancer cells through p53dependent Bax induction. FEBS Lett. 2002;512(1-3):334-40.

5. Fabianowska-Majewska K, Kaufman-Szymczyk A, Szymanska-Kolba A, Jakubik J, Majewski G, Lubecka K. Curcumin from Turmeric Rhizome: A Potential Modulator of DNA Methylation Machinery in Breast Cancer Inhibition. Nutrients. 2021;13(2):332.

6. Patra S, Pradhan B, Nayak R, Behera C, Panda KC, Das S, et al. Apoptosis and autophagy modulating dietary phytochemicals in cancer therapeutics: Current evidences and future perspectives. Phytother Res. 2021.

7. Khojaste E, Ahmadizadeh C. Catechin Metabolites along with Curcumin Inhibit Proliferation and Induce Apoptosis in Cervical Cancer Cells by Regulating VEGF Expression InVitro. Nutr Cancer. 2021:1-10.

8. Bhatia M, Bhalerao M, Cruz-Martins N, Kumar D. Curcumin and cancer biology: Focusing regulatory effects in different signalling pathways. Phytother Res. 2021.

9. Giordano A, Tommonaro G. Curcumin and cancer. Nutrients. 2019;11(10):2376.

10. Al-Ejeh F, Kumar R, Wiegmans A, Lakhani S, Brown M, Khanna K. Harnessing the complexity of DNA-damage response pathways to improve cancer treatment outcomes. Oncogene. 2010;29(46):6085-98.

11. Udagawa T, Wood M. Tumor-stromal cell interactions and opportunities for therapeutic intervention. Curr Opin Pharmacol. 2010;10(4):369-74.

12. Clusan L, Le Goff P, Flouriot G, Pakdel F. A closer look at estrogen receptor mutations in breast cancer and their implications for estrogen and antiestrogen responses. Int J Mol Sci. 2021;22(2):756.
13. Kunnumakkara AB, Anand P, Aggarwal BB. Curcumin inhibits proliferation, invasion, angiogenesis and metastasis of different cancers through interaction with multiple cell signaling proteins. Cancer Lett. 2008;269(2):199-225.

14. Shakeri A, Ward N, Panahi Y, Sahebkar A. Anti-angiogenic activity of curcumin in cancer therapy: a narrative review. Curr Vasc Pharmacol. 2019;17(3):262-9.

15. Rowe DL, Ozbay T, O'Regan RM, Nahta R. Modulation of the BRCA1 protein and induction of apoptosis in triple negative breast cancer cell lines by the polyphenolic compound curcumin. Breast cancer: basic and clinical research. 2009;3:BCBCR. S3067.

16. Banerjee M, Singh P, Panda D. Curcumin suppresses the dynamic instability of microtubules, activates the mitotic checkpoint and induces apoptosis in MCF-7 cells. The FEBS journal. 2010;277(16):3437-48.

17. Mehta K, Pantazis P, McQueen T, Aggarwal BB. Antiproliferative effect of curcumin (diferuloylmethane) against human breast tumor cell lines. Anticancer Drugs. 1997;8(5):470-81.

18. Chiu T-L, Su C-C. Curcumin inhibits proliferation and migration by increasing the Bax to Bcl-2 ratio and decreasing NF- $\kappa$ Bp65 expression in breast cancer MDA-MB-231 cells. Int J Mol Med. 2009;23(4):469-75.

19. Nagaraju GP, Aliya S, Zafar SF, Basha R, Diaz R, El-Rayes BF. The impact of curcumin on breast cancer. Integrative Biology. 2012;4(9):996-1007.

20. Chattopadhyay I, Biswas K, Bandyopadhyay U, Banerjee RK. Turmeric and curcumin: Biological actions and medicinal applications. Curr Sci. 2004:44-53.

21. Pandya N, Khan E, Jain N, Satham L, Singh R, Makde RD, et al. Curcumin analogs exhibit anti-cancer activity by selectively targeting G-quadruplex forming c-myc promoter sequence. Biochimie. 2021;180:205-21. 
